\title{
FORMATION OF PRODUCTIVITY OF SOWING PEAS DEPENDING ON TECHNOLOGY MEASURES OF CULTIVATION IN THE CONDITIONS OF THE WESTERN FOREST-STEPPE
}

\author{
Mykola Bakhmat ${ }^{1}$ \\ StepanchenkoV@i.ua \\ Oleksandr Chynchyk \\ Department of Ecology, Quarantine and Plant Protection ${ }^{2}$ \\ chinchik1978@gmail.com \\ Kateryna Nebaba ${ }^{1}$ \\ agronebaba@gmail.com \\ ${ }^{1}$ Department of Crop and Fodder Production2 \\ ${ }^{2}$ State Agrarian and Engineering University in Podilya \\ 13 Shevchenko str., Kamianets-Podilskyi, Khmelnytskyi rgn. Ukraine, 32316
}

\begin{abstract}
In the conditions of the western Forest-steppe, leguminous crops, including sowing peas, are the main and most important source of vegetable protein, which solve the biological and ecological problems of modern agriculture in Ukraine.

The article presents the main research results on the study of the effect of mineral fertilizers and growth regulators on the formation of the sowing peas productivity in the conditions of the western Forest-steppe.

The field trifactor experiment was laid in the ten-field crop rotation in Podillia Research Center of State Agrarian and Engineering University in Podilya, during 2016-2018. The field experiment was laid down in the research ten-digit crop rotation. In microstages VVSN 55-65 (budding - flowering) crops were sprayed with growth regulators PlantaPeg, Emistim C and Vympel.

The studies carried out showed that the individual productivity of plants of the Chekbek variety was the best of all the varieties that were studied. It was found, that high indices of the mass of 1000 seeds were in the variants, where mineral fertilizers were used at a dose of $\mathrm{N}_{30} \mathrm{P}_{30} \mathrm{~K}_{45}$ with the plant growth regulator Vympel. According to this fertilizer composition, the mass indices of 1000 seeds for peas of the Chekbek variety were $266.4 \mathrm{~g}$, and for the Hotivskyi and Fargus varieties - $260.6 \mathrm{~g}$ and 238.4 g, respectively.

The grain yield of peas is an integrated indicator of the action of all life factors on the plant organism during its growth and development. To a large extent, it depends on the biological characteristics of the variety, the supply of moisture and nutrients to the plant, technological methods of cultivation, as well as natural and climatic conditions. In our studies, the crops, fed with mineral fertilizers and growth regulators, were significantly less exposed to adverse factors, and the studied technology elements had a positive effect on the productivity of pea grain. The maximum biological yield was for the application of mineral fertilizers in doses of $\mathrm{N}_{30} \mathrm{P}_{30} \mathrm{~K}_{45}$ and the plant growth regulator Vympel. For the varieties of Hotivskyi peas, these indicators were $3.79 \mathrm{t} / \mathrm{ha}$, Chekbek 4.32 t/ha, and Fargus 3.30 t/ha.
\end{abstract}

Keywords: peas, variety, mineral fertilizers, growth regulators, yield, grain quality, cultivation technology.

DOI: $10.21303 / 2504-5695.2021 .001751$

\section{Introduction}

One of the important directions of the successful development of the latest agricultural technologies in crop production is the creation of highly productive agrocenoses of leguminous crops, which make the most of the bioclimatic resources of the region [1, 2]. Legumes are the main and very important source of vegetable protein and solve the biological and ecological problems of modern agriculture in Ukraine [3].

Peas have high nutritional and fodder qualities. Pea grain contains from 16 to $36 \%$ of protein, starch, sugar, fat, vitamins $\left(\mathrm{A}, \mathrm{B}_{1}, \mathrm{~B}_{2}, \mathrm{~B}_{6}, \mathrm{C}, \mathrm{PP}, \mathrm{K}, \mathrm{E}\right)$, carotene, minerals (salts of potassium, calcium, manganese, iron, phosphorus) up to $54 \%$ of carbohydrates [4]. The amount of ash in pea seeds varies considerably and depends on the soil and agricultural practices of their processing, 
climate. The average ash content is from 2 to $5 \%$, as in cereals, $75 \%$ ash consists of phosphorus and potassium. Unlike cereals, pea ash contains less magnesium, but more calcium and especially sulfur. The fat content is small within $2-3 \%$ and varies slightly in different varieties of crops. In the seeds, the fat is mainly found in the embryo $[5,6]$.

The problem of growing peas in the last decade has been associated with its harvesting, when it was separate and was carried out with a large expenditure of time and energy, and the losses reached about $80 \%$ [7]. But new varieties of foreign and national selection have appeared, suitable for direct combining, which is carried out by conventional combine harvesters with minimal losses. These are the so-called erect or half leafless varieties of peas [8-10]. Their main feature is that the upper leaves are morphologically transformed into fake whiskers, which cause additional adhesion between neighboring plants on the upper tier. However, plants, saturated with so many economically valuable traits, need proper care. First of all, special requirements for sowing material. Only the use of original seeds of high reproduction can provide the yield that was programmed by breeders $[11,12]$.

The introduction of new varieties into production allows more efficient use of material and technical resources and improves the quality of marketable and seed products [13]. The elements of the technology for growing peas should be aimed at creating optimal conditions for the growth and development of plants at each stage of ontogenesis, and otherwise will lead to a decrease in yield. Compliance with the basic technological conditions for growing peas will allow realizing the genetic potential of new varieties and obtaining high and stable yields and high-quality grain [14-16].

Favorable weather conditions and temperature regime, present during the growing season and especially from the beginning of the laying of generative organs to flowering, have the greatest influence on the productivity and quality of the sowing pea grain [17].

Compared to other legumes, peas have good grain quality and a short growing season. It is one of the best precursors for winter cereals [18-20].

The purpose of the research was to study the peculiarities of the formation of the yield of sowing pea, depending on the effect of mineral fertilizers and growth regulators in the conditions of the western Forest-steppe.

\section{Materials and methods}

\section{1. Agrochemical characteristics of the experimental site soil}

Laboratory analyzes of soil were carried out in Khmelnytskyi Regional State Technological Center for Soil Fertility Protection and Product Quality according to the following methods: $\mathrm{pH}$ of aqueous and saline suspensions and hydrolytic acidity by the Kappen method; the number of absorbed bases by the Kappen-Gilkowitz method; humus content according to Tiurin; alkaline hydrolyzed nitrogen according to Cornfield; mobile compounds of phosphorus and potassium by the modified Chyrikov method [21-24].

The soil of the experimental field is typical black soil (chernozem), deep low-humus heavy loam on loess-like loam. According to the research results of the Department of Agriculture, Soil Science and Plant Protection of State Agrarian and Engineering University in Podilya, it was established, that the experimental site is characterized by the following agrophysical and agrochemical soil properties: the density of the solid phase of the $0-30 \mathrm{~cm}$ soil layer is $2.55-2.62 \mathrm{~g} / \mathrm{m}^{3}$; pH of aqueous and salt suspensions and hydrolytic acidity according to the Kappen method in the modification of TsINAO (GOST 26212-91). Thus, the aqueous $\mathrm{pH}$ in the upper layer is: 6.8 a, hydrolytic acidity is $0.70 \mathrm{mg}$-eq./100 $\mathrm{g}$ of soil. The content of humus according to Tiurin in the modification of TsINAO (GOST 26213-84) in the upper horizon is $3.39 \%$. Density of folding $-1.17-1.25 \mathrm{~g} / \mathrm{m}^{3}$; total porosity $-51.6-54.7 \%$, nitrogen content (according to Cornfield) - 13.6-14.2, phosphorus and potassium according to Chyrikov (DSTU-4115-2002) - 15.7-16.4 and 22.4-26.3 mg per $100 \mathrm{~g}$ of soil, respectively. Absorption capacity at the level of 20-25 mg-eq./100 g of soil.

\section{2. The scheme of the experiment and research methods}

The field research envisaged the study of the growth, development, and productivity of sowing peas varieties, depending on fertilization with mineral fertilizers and growth regulators in the conditions of the western Forest-steppe. 
The field experience was laid in the ten-field research crop rotation of the Podillia Research Center during 2016-2018.

The experiment studied the effect and interaction of three factors: A - varieties; B - mineral fertilizers; C - growth regulators (Table 1).

Table 1

The scheme of the experiment

\begin{tabular}{ccc}
\hline Factor $\boldsymbol{A}$ : variety & Factor $\boldsymbol{B}$ : fertilizers & Factor $\boldsymbol{C}$ : growth regulators \\
\hline$A_{1}-$ Hotivskyi (control) & $B_{1}-\mathrm{P}_{30} \mathrm{~K}_{45}$ (control) & $C_{1}$ - without growth regulators (control) \\
$A_{2}-$ Chekbek & $B_{2}-\mathrm{N}_{15} \mathrm{P}_{30} \mathrm{~K}_{45}$ & $C_{2}-$ Emistim C \\
$A_{3}-$ Fargus & $B_{3}-\mathrm{N}_{30} \mathrm{P}_{30} \mathrm{~K}_{45}$ & $C_{3}-$ PlantaPeg \\
& $B_{4}-\mathrm{N}_{45} \mathrm{P}_{30} \mathrm{~K}_{45}$ & $C_{4}-$ Vympel
\end{tabular}

Our research aimed to investigate and compare intensive varieties of sowing peas (factor A), recommended for the Forest-steppe zone.

The originator of the Hotivskyi variety, which was taken for control, is the company "Axial Eximpo Prague" (Czech Republic), added to the State Register of Ukrainian varieties in 2006. The variety is a high-yielding, intensive type, suitable for mechanized harvesting. By ripeness group - mid-season. According to the applicant, the recommended seeding rate is $1.0-1.2 \mathrm{ml} /$ ha of germinating seeds.

The mid-ripening pea variety Chekbek was added to the State Register of Varieties in 2009. The originator of the variety is the Plant Production Institute nd. a. V. Ya. National Academy of Agrarian Sciences. This variety is suitable for direct harvesting. The recommended seeding rate, depending on the growing area of this variety, is 1.2-1.4 mln of germinating seeds per hectare.

In 2007, the pea variety Fargus was added to the State Register of Varieties of Ukraine, the applicant of which is the Research and Production Corporation "Stepova" LLC (Dnipro). The intensive type variety is suitable for mechanized harvesting. According to the applicant, the sowing rate is from 1.0 to $1.2 \mathrm{ml} /$ ha of similar seeds.

Phosphorus and potassium fertilizers were applied to the main tillage in autumn, and nitrogen fertilizers were applied in spring under pre-sowing tillage.

Pea crops of all three studied varieties were sprayed with plant growth regulators (factor $C$ ) in the micro stage BBCH 55-65 (the first flower buds appear, but the flowers are still closed - full flowering, $50 \%$ of the flowers are open). Emistim $\mathrm{C}$ growth bioregulator with a broad spectrum of action - a product of biotechnological cultivation of epiphytic fungi from the root system of medicinal plants was used at a dose of $30 \mathrm{ml} / \mathrm{ha}$. Plant growth regulator PlantaPeg (active substance polyethylene glycol (PEG) 400 and polyethylene glycol (PEG) - 1500, $800 \mathrm{~g} / \mathrm{l}$, fulvic acids and salts of humic acids, $4 \mathrm{~g} / \mathrm{l}$ ) was used with the recommended application rate of $25 \mathrm{~g} / \mathrm{ha}$. Vympel - a contact-systemic growth regulator, intended for the treatment of seeds and vegetative plants, the active ingredient is polyethylene oxide (PEO) - $770 \mathrm{~g} / \mathrm{l}$, washed salts of humic acids up to $30 \mathrm{~g} / \mathrm{l}$ for the solution, used at a dose of $30 \mathrm{ml} / \mathrm{ha}$.

The sown area of the elementary plot was $0.50 \mathrm{~m}^{2}$, the accounting area $-0.48 \mathrm{~m}^{2}$. The predecessor is winter wheat. The soil cultivation was carried out due to generally accepted for the Forest-steppe zone of Ukraine mode.

The seeds were sown with a grain seeder, in the usual line method with a row spacing of $15 \mathrm{~cm}$, with a seeding depth of 5-6 cm and a seeding rate of $1.2 \mathrm{mln} /$ ha of germinating seeds for all studied varieties of sowing peas. After sowing on the $2^{\text {nd }}$ day, the sowing area was rolled with a ring roller. The studies were carried out according to the scheme in a trifactor field experiment by the method of randomized split areas. The variants are repeated four times.

The grain yield was determined on the counting part of the plots by the method of continuous collection and weighing the grain of each plot, followed by the determination of moisture and debris. To determine the mass of 1000 seeds from a grain of peas, two replicates of 500 seeds were manually deducted without selection and weighed with an accuracy of one-hundredth of a gram. In the case, when the actual discrepancy exceeds the allowable, the third repetition was taken [25-27]. 


\section{Results}

The maximum indices of the mass of 1000 seeds were in the peas of the Chekbek variety in the feeding areas of $\mathrm{N}_{30} \mathrm{P}_{30} \mathrm{~K}_{45}$ in combination with the Vympel growth regulator and amounted to $266.4 \mathrm{~g}$, for the same dose of mineral fertilizers and growth regulators Emistim C and PlantaPeg, respectively $265.7 \mathrm{~g}$ and $264.9 \mathrm{~g}$. This fertilizer composition also had a positive effect for varieties Hotivskyi and Fargus, these indicators were 257.2-260.6 g and 235.1-238.4 g, respectively.

Yields on feeding options of $\mathrm{N}_{30} \mathrm{P}_{30} \mathrm{~K}_{45}$ in combination with growth regulators Emistim $\mathrm{C}$ and Vympel were respectively 3.71-3.79 t/ha for the variety Hotivskyi, 4.15-4.32 $\mathrm{t} /$ ha for the variety Chekbek, and the lowest yield was in variety Fargus 3.22-3.30 t/ha. The effect of PlantaPeg growth regulator had a smaller influence, but the biological productivity of peas was higher than the option without treatment with growth regulators and ranged from 3.13 to 4.0 t/ha depending on the variety (Table 2).

Table 2

Influence of mineral fertilizers and growth regulators on the individual productivity of peas (average for 2016-2018)

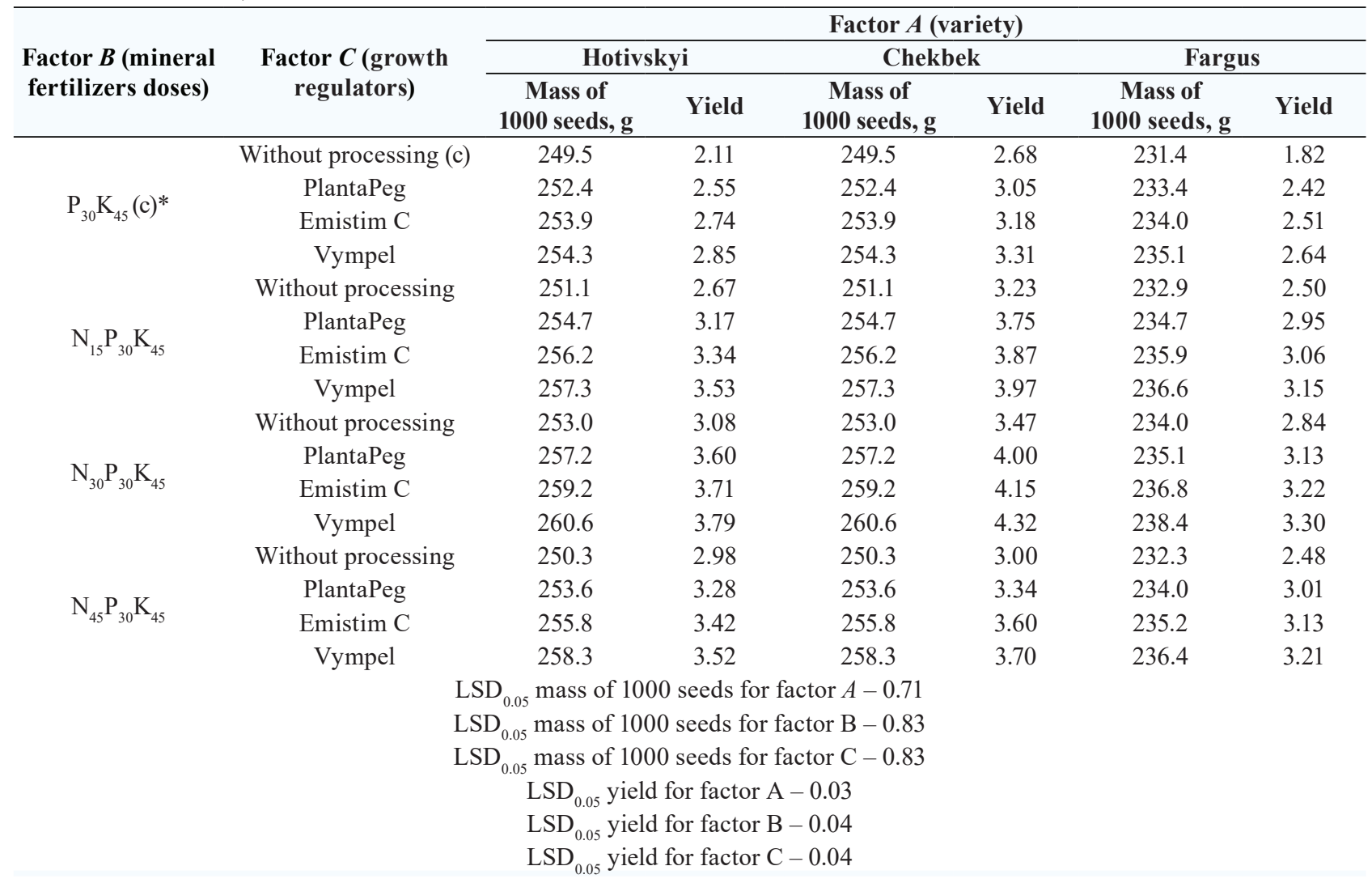

Note: Footnote $*-(c)-$ control.

\section{Discussions}

Harvest structure analysis is an important method for assessing crop development. The main elements of the structure of the pea yield include the number of plants, preserved for harvesting, the number of beans per plant, the number of seeds in a bean, and the mass of 1000 seeds [28-30].

One of the important indicators of the yield structure is the mass of 1000 seeds, which in our studies depended on the varietal characteristics of the crop, the introduction of various doses of mineral fertilizers, and growth regulators. In the Hotivskyi pea variety, the mass of 1000 grains ranged from 249.5-260.6 g, Chekbek 261.1-266.4 g, and Fargus 231.4-238.4 g, depending on the applied cultivation techniques.

In the $\mathrm{P}_{30} \mathrm{~K}_{45}$ fertilizer variants without spraying the plants with growth regulators, the Hotivskyi pea variety provided a mass of 1000 grains of $249.5 \mathrm{~g}$, Chekbek - 261.1 g, and Fargus - $231.4 \mathrm{~g}$. 
After spraying the crops with PlantaPeg, Emistim C and Vympel growth regulators, the mass of 1000 seeds did not increase significantly, on average by $2.8-4.8 \mathrm{~g}$, depending on the variety. With the addition of nitrogen in the norm $\mathrm{N}_{15}, \mathrm{~N}_{30}$, and $\mathrm{N}_{45}$, but without growth regulators, the mass increased for the variety Hotivskyi by 1.6-3.5 g, for the variety Chekbek by 1.4-2.7 g, and Fargus by 1.5-2.6 g.

Grain yield is an integrated indicator of the effect of all life factors on a plant organism during its growth and development. In our studies, it largely depended on the biological characteristics of the variety, the supply of moisture and nutrients to the plant, the technological methods of cultivation, as well as the natural and climatic conditions. The pea varieties Hotivskyi, Chekbek, and Fargus, intensive type, have a high yield potential, adapted to growing conditions in the western Forest-steppe.

Favorable conditions for the growth and development and realization of the biological productivity of peas were created with the introduction of mineral fertilizers in doses of $\mathrm{N}_{30} \mathrm{P}_{30} \mathrm{~K}_{45}$, with the finishing of crops with growth regulators, which, in extremely low concentrations, significantly changed the processes of their vital activity in plants and contributed to an increase in the yield of pea grain.

On the $\mathrm{N}_{45} \mathrm{P}_{30} \mathrm{~K}_{45}$ fertilizer variants without treatment with growth regulators, the average grain yield for three years in Hotivskyi, Chekbek, and Fargus pea varieties was $2.98 \mathrm{t} / \mathrm{ha}, 3,00$ and $2.48 \mathrm{t} /$ ha, respectively. After spraying the plants with regulators, the yield increased by $18-19 \%$ compared to variant $\mathrm{P}_{30} \mathrm{~K}_{45}$, while in the variants of fertilizers, where mineral fertilizers were applied in doses of $\mathrm{N}_{30} \mathrm{P}_{30} \mathrm{~K}_{45}$ and growth regulators, these figures increased by $23-25 \%$. Due to this, only mineral fertilizers in doses of $\mathrm{N}_{45} \mathrm{P}_{30} \mathrm{~K}_{45}$ were less effective.

\section{Conclusions}

Over the years of research, study, and detailed analysis of the grain of the sowing pea varieties Hotivskyi, Chekbek, and Fargus, it was established, that the mass of 1000 seeds depended on the varietal characteristics of the crop, the introduction of various doses of mineral fertilizers and growth regulators. In the Hotivskyi pea variety, the mass of 1000 grains ranged from 249.5 to 260.6 g, Chekbek 261.1 to $266.4 \mathrm{~g}$, and Fargus 231.4 to $238.4 \mathrm{~g}$.

The application of mineral fertilizers in doses of $\mathrm{N}_{30} \mathrm{P}_{30} \mathrm{~K}_{45}$ in combination with growth regulators Emistim $\mathrm{C}$ and Vympel had the best effect on the biological productivity of peas. Yields in these variants were 3.71-3.79 t/ha for Hotivskyi, 4.15-4.32 t/ha for Chekbek, and 3.22-3.30 t/ha for Fargus.

The introduction of higher norms of nitrogen fertilizers $\mathrm{N}_{45} \mathrm{P}_{30} \mathrm{~K}_{45}$ less effectively influenced the biological productivity of pea grain since the introduction of mineral nitrogen in a higher dose led to the suppression of the symbiotic and photosynthetic apparatus, these are the main indicators for the formation of the yield of leguminous crops.

\section{Conflicts of interest}

There is no conflict of interest

\section{References}

[1] Horbatenko, A., Sudak, V., Chaban, V. (2019). Horokh zavzhdy prybutkovyi, i na skhylakh tezh. Propozytsiya, 1, 56-59.

[2] Zhuikov, A. G., Lahutenko, K. V. (2016). Green peas in Ukraine: state, problems, prospects (a review article). Tavriyskyi naukovyi visnyk, 98, 65-71. Available at: http://www.tnv-agro.ksauniv.ks.ua/archives/98_2017/13.pdf

[3] Kalenska, S. M., Yermakova, L. M., Palamarchuk, V. D., Polishchuk, I. S., Polishchuk, M. I. (2015). Systemy suchasnykh intensyvnykh tekhnolohiy u roslynnytstvi. Vinnytsia, 448.

[4] Kashukoev, M. V., Gazhev, H. A. (2006). Soderzhanie, sbor belka i zhira s semyan soi i goroha. Zernovoe hozyaystvo, 7, $24-26$.

[5] Lykhochvor, V. V., Petrychenko, V. F. (2006). Suchasni intensyvni tekhnolohiyi vyroshchuvannia osnovnykh polovykh kultur. Lviv: Ukrainski tekhnolohiyi, 730.

[6] Palamarchuk V. D., Polishchuk I. S., Mazur V. A., Palamarchuk O. D. (2017). Novitni ahrotekhnolohiyi u roslynnytstvi. Vinnytsia, 602.

[7] Prysiazhniuk, O. I., Kaliuzhna, E. A., Ukrainets, V. V., Shevchenko, O. P. (2013). Otsinka sortiv horokhu za kompleksom hospodarskotsinnykh oznak. Tsukrovi buriaky, 5, 16-17. Available at: http://nbuv.gov.ua/UJRN/Cb_2013_5_7

[8] Stolyarov, O. V., Zhbanov, D. V. (2010). Sortovaya agrotehnologiya goroha. Agrarnaya nauka, 10, 16-17.

[9] FAO Statistical Yearbook 2014 Near East and North Africa Food and Agriculture (2015). Food and Agricultural Organization of United Nations. Cairo. Available at: http://www.fao.org/3/i3591e/i3591e.pdf 
[10] Prysiazhniuk, O. I., Serhieiev, L. A, Konashchuk, O. P (2018). Vyroshchuvannia nasinnievoho horokhu na pivdni Ukrainy. Ahronom, 4, 138-140.

[11] Didur, I. M. (2008). Optymizatsiya modelei tekhnolohiy vyroshchuvannia horokhu na zerno v umovakh Pravoberezhnoho Lisostepu Ukrainy. Kormy i kormovyrobnytstvo, 63, 251-257.

[12] Kaminskyi, V. F., Dvoretska, S. P., Kostyna, T. P. (2012). Vplyv peredposivnoi obrobky nasinnia mikroelementamy ta biolohichnymy preparatamy na urozhainist horokhu. Zemlerobstvo, 84, 82-87.

[13] Vyshnivskyi, P. S., Furman, O. V. (2020). Soybean productivity depending on elements of growing technology in the rightbank forest-steppe of Ukraine. Plant and Soil Science, 11 (1), 13-22. doi: https://doi.org/10.31548/agr2020.01.013

[14] Dvoretska, S. P., Riabokin, T. M., Yefimenko, H. M. (2014). Osoblyvosti formuvannia elementiv produktyvnosti roslyn horokhu zalezhno vid rivnia intensyfikatsiyi tekhnolohiyi vyroshchuvannia kultury. Zbirnyk naukovykh prats "NNTs Instytut zemlerobstva NAAN", 3, 56-66.

[15] Nahornyi, V. I., Petrychenko, V. F. (2009). Pat. No. 44315 UA. Method for determination of weight of 1000 seeds of soya, pea and vetch. No. u200905203; declareted: 25.05.2009; published: 25.09.2009, Bul. No. 18.

[16] Novikova, N. E., Fomin, D. M. (2011). Vliyanie morfotipa lista u goroha na pokazateli vodnogo obmena, opredelyayuschie ustoychivost' rasteniy k zasuhe. Vestnik Orel GAU, 3 (30), 13-17.

[17] Popov, B. K. (2006). Selektsiya tehnologichnyh sortov goroha. Vestnik RASHN, 3, 22-23.

[18] Chekalin, E. I., Kondykov, I. V., Amelin, A. V. (2011). Ustoychivost' goroha posevnogo i polevogo k ekstremal'nym faktoram pogody. Novye sorta sel'skohozyaystvennyh kul'tur - sostavnaya chast' innovatsionnyh tehnologiy v rastenievodstve, 297-303.

[19] Chinchik, A., Olifirovich, S., Olifirovich, V., Tretiakova, S. (2019). Perspectives of biologization of cultivation of leguminous crops in Ukraine. Collected Works of Uman National University of Horticulture, 94 (1), 198-207. doi: https://doi.org/ 10.31395/2415-8240-2019-94-1-198-207

[20] Nebaba, K. S. (2020). The influence of mineral fertilizers and growth regulators on crop productivity of field pea varieties in the conditions of Western Forest-Steppe. Interagency Thematic Scientific Collection «Irrigated Agriculture», 74, 65. doi: https://doi.org/10.32848/0135-2369.2020.74.10

[21] Chinchik, O. S. (2014). Vliyanie udobreniy na kachestvo zerna sortov goroha v usloviyah Zapadnoy Lesostepi Ukrainy. Agrarnaya nauka - sel'skomu hozyaystvu: IX mezhdunar. nauch. - prakt. konf. Kn. 2. Barnaul: RIO AGAU, 326-327.

[22] Dyachenko, E. A., Ryzhova, N. N., Vishnyakova, M. A., Kochieva, E. Z. (2014). Molecular genetic diversity of the pea (Pisum sativum L.) from the Vavilov Research Institute collection detected by the AFLP analysis. Russian Journal of Genetics, 50 (9), 916-924. doi: https://doi.org/10.1134/s102279541409004x

[23] Stolyarov, O. V., Zhbanov, D. V. (2010). Sortovaya agrotehnologiya goroha. Agrarnaya nauka, 10, 16-17.

[24] Volkodav, V. V., Andrushchenko, A. V., Pilkevych, A. V. (2000). Metodyka derzhavnoho sortovyprobuvannia silskohospodarskykh kultur. Kyiv, 100.

[25] Skrypnyk, M. P. (Ed.) (1993). Dovidnyk z ahroklimatychnykh resursiv Ukrainy. Ch. 2.: Ahroklimatychni umovy rostu ta rozvytku osnovnykh silskohospodarskykh kultur. Kyiv, 718

[26] Sukhova, H. I. (2012). Formuvannia elementiv produktyvnosti sochevytsi zalezhno vid osoblyvostei sortu. Visnyk Kharkivskoho natsionalnoho ahrarnoho universytetu im. V. V. Dokuchaieva. Seriya: Roslynnytstvo, selektsiya i nasinnytstvo, plodoovochivnytstvo, 2, 106-111.

[27] Chernyuk, A. P. (2013). Prospects and technology of growing peas. Naukovi pratsi Instytutu bioenerhetychnykh kultur i tsukrovykh buriakiv, 18, 69-72.

[28] Dospehov, B. A. (1985). Metodika polevogo opyta. Moscow: Agropromizdat, 351.

[29] DSTU 4115-2002. Grunty. Vyznachannia rukhomykh spoluk fosforu i kaliyu za modyfikovanym metodom Chyrykova.

[30] Yeshchenko, V. O., Kopytko, P. H., Kostohryz, P. V.; Yeshchenko, V. O. (Ed.) (2014). Osnovy naukovykh doslidzhen v ahronomii. Vinnytsia: Edelveis i K, 332.

How to cite: Bakhmat, M., Chynchyk, O., Nebaba, K. (2021). Formation of productivity of sowing peas depending on technology measures of cultivation in the conditions of the western forest-steppe. EUREKA: Life Sciences, 2, 3-8. doi: https://doi.org/10.21303/ 2504-5695.2021.001751 